Gordana Bekčić Pješčić, PhD*

\title{
US LEGAL SYSTEM IN THE CONTEXT OF ENGLISH LEGAL HERITAGE AND THEORY OF THE NATURAL RIGHTS OF JOHN LOCKE
}

\author{
Abstract
}

The paper discusses several characteristics of the US legal system that rest upon English legal heritage, brought from England to North America by the first colonists. The author starts from the premise that constant modifications of basic principles of English common law system and legal and judicial practice gave rise to a specific US legal system that has a dual nature, based on common law principles on the one hand and the letter of the written law on the other. ${ }^{l}$ The paper also analyzes the legacy of the philosophical system of John Locke on natural rights, the status of property and the government on establishing American political and legal thought, embodied in the Declaration of Independence and the Bill of Rights.

Keywords: US legal system, legal heritage, US Constitution, common law, natural rights, judicial review, precedent.

\section{Legacy of English Common Law}

The US legal system was developed on the legacy of English common law, where it identified as its key institute the one of precedent, at least for the US. While the English legal system formed two categories of courts of $l^{2}{ }^{2}$, quite a unique judicial model developed in the US, combining the elements of common and precedent law, with the parallel development of written legislation. Colonists felt slightly resistant to the

\footnotetext{
* The author holds a PhD degree in political science, in the field of American Studies. Currently works as an independent PR and communications consultant, e-mail: gordana.bekcic@pjescic.rs. ${ }^{1}$ The paper presents the part of material from Chapter Five of the author's PhD dissertation, "US Political and Legal Values in light of American Critical Thinking of 19th Century", defended at the Faculty of Political Sciences, University of Belgrade, September 2018.

${ }^{2}$ For integral overview of US law consult E.A. Farnsworth, Uvod u pravni sistem Sjedinjenih Američkih Država, Savremena administracija, Beograd 1973. Also: David S. Clark, David, Turgul Ansay (eds.), Introduction to the Law of the United States, Kluwer Law International, The Hague 2002.
} 
English legal system, and the pace and specific nature of colonial life development did not allow for legal practices to be simply transferred. The practices were adjusted, and also "some kind of traditional law derived from the Bible was enforced, as well as local customs and so on"3.

The main principles taken over from the common law system were the idea of the rule of law, the precedent institute, and the concept of trial as litigation, with two opposing parties before the jury. English supremacy of law had a key political impact on the development of US civil society. ${ }^{4}$ The issue of rights of the colonists as English subjects, and their right to have representatives in the Parliament, were indeed the legal and political axis of the War of Independence 5 . This issue arose from English legal heritage founded by Magna Carta ${ }^{6}$ and limitations to sovereign's powers. The supremacy of law influenced also establishment of the institute of judicial review $^{7}$. It remained a fundamental principle in the US legal order as well, but here each individual legal situation required additional observation and conclusions, since the system of written laws developed in parallel with the common law system, especially at the federal level. This dual legal system, both at the federal and state levels, represents a unique combination of the common law system and written legislation, where the Constitution is the "supreme Law of the Land" constitutionality of acts. Although English doctrine of precedent is indeed a dominant legal practice in the USA, the common law tradition was not taken over in full, due to a number of reasons: colonists resisting English institutions, lack of educated jurists, many procedures and legal practices ill adjusted to the conditions of colonial life, dynamic social and economic development of the colonies, and later of the US as well.

All that called for legal modifications of English legal heritage which, given time, created a unique legal system of the USA. What gave rise to this difference were a completely new experience of the colonial life, legal vacuum requiring the creation of legal space ex nihilo, lack

\footnotetext{
${ }^{3}$ D. Vranjanac, "Uvod u pravni sistem Sjedinjenih Američkih Država“, Uvod u pravo SAD (ed. Jovan Ćirić), Institute for Comparative Law, Belgrade 2008, 16.

${ }^{4}$ This corresponds with philosophical systems of the epoch, primarily with theories by Locke, Montesquieu and Scottish Enlightenment.

${ }^{5}$ Political statement "No taxation without representation" meant that colonists found themselves not obliged to pay tax to the English crown due to the fact that they did not have their political representatives in the Parliament.

${ }_{7}^{6}$ Magna Carta Libertatum (1215), https://www.bl.uk/collection-items/magna-carta-1215.

${ }^{7}$ The power of the courts to declare violation of the US Constitution by legislative or executive act. The doctrine established by the Chief Justice, John Marshal, in the Marbury v. Madison (1803) case.

${ }^{8}$ Article 6, clause 2, United States Constitution, https://www.archives.gov/founding-docs/constitution-transcript.
} 
of theoretical and practical legal knowledge in most law practitioners, creation of legal practices while facing actual life in colonies, legal practices as support to establishing colonies as political communities and as support to the colonists' religious tasks ${ }^{9}$, contractual relationship between the colonies and Mother Country ${ }^{10}$, impact of philosophic theories of the Enlightenment, practice of writing down legal transactions, sturdy bureaucratic apparatus of the British rule not being present in the colonies, absence of clearly divided social strata, absence of hereditary nobility, need for developed legal practice in order to realize and protect economic interests of the colonies.

In the US legal system, the doctrine of precedent is prevalent to this very day, but it is important to highlight that "there this stare decisis doctrine ${ }^{11}$ never had the importance it had in England. American justice often restricted the scope of earlier rulings, at times taking even opposing views if need be, which resulted from weaker presence of centralization and the necessity of constant adaptation of the law to social needs". ${ }^{2}$ Jury trials led to situations where the focus of the court proceedings was on the process $^{13}$ or on the prosecutor ${ }^{14}$, the judge played no inquisitorial role, and all the attention was paid to the process of presenting evidence and the verdict of the jury. When this is compared to the position of the judiciary within the state apparatuses at the federal and state levels it can be seen that the presence of the jury was the channel that served to preserve, to a large extent, the institution of proceedings in equity, in addition to the function of the judge, also one of the guardians of this system in the USA.

In early $17^{\text {th }}$ century North America was terra incognita to all intents and purposes. Intensive legal regulation was necessary in order to regulate the life of the community, prevent anarchy and ensure survival. Shortage of educated jurists led to many colonists without education being included into legal processes, and thus learning legal logics, terms and expressions, a legal way of thinking. Economic development generated the need for

\footnotetext{
${ }^{9}$ Particularly refers to the colonies of New England.

${ }^{10}$ Colonial charters were official acts and in fact contracts by which the King of England gave right to the settlers to establish a colony (e.g. Massachusetts was established by Massachusetts Bay Colony) or to the individuals (Lord of Baltimore was the founder of the colony of Maryland).

11 "According to the stare decisis doctrine, cases whose factual framework is similar to an earlier case that has already been resolved in the past by a precedent, will be judged in the same way. The stare decisis and non quieta movere principle - to abide by the decisions already made and the issues solved not to be disturbed.", $\mathrm{S}$. Danković Stepanović, Pravo i politika konkurencije, Fakultet političkih nauka, Beograd 2014, 300.

12 J. Ćeranić, ,Izvori američkog prava“, Uvod u pravo SAD (ed. Jovan Ćirić), Institute for Comparative Law, Belgrade 2008, 23.

${ }^{13}$ In civil disputes.

${ }^{14}$ In criminal proceedings.
} 
legal transactions and for the colonists to be protected from England. All of that happened on the platform English legal tradition, suffering significant changes in the new conditions. Continuity of legal practice in the colonies, outside of the religious discourse, was additionally strengthened by theories of John Locke, Montesquieu and Scottish Enlightenment. ${ }^{15}$ The philosophy of enlightenment made the legal discourse into a creator of the idea of separation of church and state, which will be defined by the First Amendment. ${ }^{16}$

The experience of legal regulation led to the efforts aimed at legal advancement of the society and radical thinking, since "nothing is more characteristic of American society than efforts to reform it. From the earliest days of colonial settlement, virtually every generation has witnessed some endeavor to improve the institutions of American life." ${ }^{\prime 17}$ The emergence of radicalism was brought about by religious confessions, Puritans and Quakers in particular, and Anglicans to a smaller degree, while Virginian political activism played a significant role. ${ }^{18}$ Daily practicing and exercise of law had an exceptional impact on these processes. On the eve of the War of Independence the colonists had acquired ample experience in law and legal practice, since they had been practicing legal discussions on freedoms and rights for over 170 years of the colonial period ${ }^{19}$. English legal heritage had taught them critical thinking about freedom, equality, rights of man, and political representation. It was on the matrix of English common law that they learned future American values that would be voiced by the Declaration of Independence and the US Constitution.

\section{Natural Law and Individual Liberty in the New World}

The legal debate between the colonies and England during the pre-revolutionary period concerned the liberties and rights of colonists as English subjects. Their arguments were based on Locke's theory of

\footnotetext{
${ }^{15}$ Scottish Enlightenment was a period in $18^{\text {th }}$ and early $19^{\text {th }}$ centuries, characterized by intensive intellectual development and work of a significant generation of thinkers such as David Hume, Adam Smith, Tomas Reid, Adam Ferguson, Joseph Black. One of the most influential was Adam Smith (1723-1790), with his groundbreaking book, An Inquiry into the Nature and Causes of the Wealth of Nations (1776). He opposed the theory of mercantilism, which defined English economic system at that time.

${ }^{16}$ This principle had religious roots and emerged even before the Bill of Rights (1791). One of the acts prior to the Declaration was The Virginia Statute for Religious Freedom.

${ }^{17}$ E. Fonner, Radical Individualism in America: Revolution to Civil War, https://www. libertarianism.org/ publications/essays/radical-individualism-america-revolution-civil-war, last accessed on November 27, 2017. ${ }^{18}$ Virginian colonial higher classes were deeply devoted to political activity and political thought.

${ }^{19}$ The Watertown Protest against taxation without representation is considered to be the earliest civil protest in the colonies, caused by the issues of economic freedom and rights. See in W. M. West, A Source Book of American History to 1787, Allyn and Bacon, Boston-New York-Chicago 1913, 180.
} 
natural law. According to Locke, natural rights are right to life, body, liberty and property. Identifying a link between liberty and property, i.e. ownership, is a revolutionary novelty that will significantly affect the dialectics of this relationship in the US political thought and legal practice. There is a dichotomy in understanding property in Locke's system. In its narrower meaning, Locke understands property as ownership over the material things. In its broader sense, the term refers to the man's inner world, his being, which comprises ideas, desires, ambitions and thoughts. Property is therefore, according to Locke, man's essential possession, where no government should enter if just and constrained by laws. The idea of property is the principle that would serve as foundation for the most famous principle of the Declaration of Independence - the right to the pursuit of happiness. It is this principle that took the place of Locke's right to property in the Declaration of Independence. The right to the pursuit of happiness has the capacity to include every individual act of freedom that the man exercises in order to have a life after his own heart. This expression includes also the notion of property in terms of material possession, but the conceptual context of pursuit for happiness leaves infinite room for individual interpretations, allowing each man the choice of the best life in line with his personality.

Colonial practice anticipated Locke's ideas that, in legal and political terms, would be realized in the outcomes of the American Revolution establishment of the USA and the new form of government that both Locke and the Founding Fathers deemed necessary in order to protect, in the multitude, the liberty and rights of each individual in the body politic. The government is the mechanism to bridge over the dangers of the natural state of freedom, and it is established by way of agreement among free men. Consensus makes legitimate the enforcement of the rule of the established political body over those who transferred to that body part of their own liberties, powers and authorities. For Locke the issue of consent of the governed is basis for the good rule and legitimacy of the government aspiring to be just and fair, and the Founding Fathers would shape that into an electoral system at two levels of government, executive and legislative. Liberty is the premise giving rise to the position that at the roots of every government there is consent, whereas later deviations and degenerations arise from other causes, such as absence of positive laws, abuse of the prerogative, or human actions. Since only a part of the mentioned prerogatives is transferred to the government, 
then absolute power over people is against the natural $\operatorname{law}^{20}$. Thus, for Locke the legislative government is the true supreme power, since it protects the freedom that is embodied through well-ordered laws. The US Constitution in its main part mostly adheres to the position of the legislative power imperative, but what can be seen in the case of the USA is that prerogatives of the executive branch became stronger over time ${ }^{21}$, so that currently the position of the US President has characteristics of a monarch in many aspects ${ }^{22}$, which is a degenerative process, if the original premises of the creators of the Constitution are taken into account.

Locke, however, despite his position that the idea of good is inherent to man, had no faith in equality in absolute terms, believing that within the political community the man is made to obey not by his conscience, but by knowledge of the right of government to exercise power defined by the laws. And in that the Founding Fathers would take their cue from him when drafting the US Constitution. In the footsteps of Locke and even more of Thomas Hobbes, American legislators show little trust in human honesty, but always believe that the man is smart. During the Constitutional Convention, the Founders would, as was explicitly noted in Federalist Papers $^{23}$ and Madison's notes ${ }^{24}$, rely on personal human interests in obeying the law, and much less on the principle of the good in the man.

Locke's theoretical system on natural law and individual liberty found its way into the following American values in the Declaration and the Constitution: separation of church from state, negative definition of powers of federal government by the formula "Congress shall make no law", right to keep and bear arms, individualism and entrepreneurship, relying on your own strength, and spatial mobility. However, it is accepted as correct that the idea of rule of law is relatively controversial, since according to the theory of natural law "the rule of law is opposed to

\footnotetext{
${ }^{20}$ It was the essence of the colonial disputes with England, ending in the American Revolution. The colonists were convinced that the English Parliament jeopardized their natural rights, as well as the contractual agreements between the King and particular colonies, also defined within the context of natural law and natural rights.

${ }^{21}$ From President Polk to Theodore Roosevelt, from early $20^{\text {th }}$ century and later on, and also by individual acts of the elected presidents.

${ }^{22}$ See in D.W. Brogan, The Highest Office, http://www.americanheritage.com/content/highest-office, accessed on November 2, 2017.

${ }^{23}$ Federalist Papers (other title: The Federalist), is a collection of 85 essays written by three Founding Fathers, Alexander Hamilton, James Madison, and John Jay, in order to promote and support the ratification of the US Constitution. See A. Hamilton, Dž. Medison, Dž. Džej, Federalistički spisi, Radnička štampa, Beograd 1981.

24 James Madison's, Notes of Debates in the Federal Convention of 1787, represent the collection of his records written during the Constitutional Convention.
} 
any system of government that allows public officials to exercise broad, arbitrary or discretionary powers of coercion. As such, the rule of law was embedded into the context of individualism of the common law system" 25 and ensured through numerous mechanisms such as common sense, pragmatism, jury trial with initiative of the parties, judicial interpretation of the legal norm, legal certainty, habeas corpus, free exercise clause, confrontation clause ${ }^{26}$, allowing for constant reviewing of boundaries to the citizen's liberty versus the political community.

\section{Fusion of Law and Equity and civil rights}

In the US legal system, the principle of equity is one of the essential categories. The presumption of fair trial and legal certainty for the parties is exercised only in the presence of independent and unbiased judicial system. The equity of court proceedings ensures protection of citizens before the state apparatus. Equity is understood as "the idea of justice applied in practice. The term 'justice' would denote an abstract idea, while the term 'equity' would denote the application of this abstract idea to concrete cases. Equity is, thus, concrete embodiment of justice in individual legal situations" 27 , and "since law and justice need not be the same, then, by introducing equity into the immediate legal life (ius aequum), rigid legal norms become more subtle, more appropriate for the true wealth of diversity that a legal norm must cover"28. Equity in judicial proceedings involves, therefore, considering an individual legal situation as unique and unrepeatable, while taking into account all the particular circumstances that indirectly and directly led to that situation.

The fusion of law and equity in the US legal system made the citizen safe in relation to the structures of power, and at the same time, combining the practices of common and written law, left room for several relevant interpretations of legal norms in each individual case. The principle of equity is preserved in the precedent doctrine at the federal and state levels since it is "that curious, almost universal sense of justice that urges that all men are

\footnotetext{
${ }^{25}$ S. Perović, Besede sa Kopaonika, sopstveno izdanje, Beograd 1997, 35.

${ }^{26}$ Confrontation Clause, referring to the $6^{\text {th }}$ Amendment to the Constitution, states, inter alia, that the accused has the right " to have compulsory process for obtaining witnesses in his favor, and to have the Assistance of Counsel for his defense".

${ }^{27}$ R. Knežević, O pravdi, pravičnosti, pravu, https://blog.aks.org.rs/o-pravdi-pravicnosti-pravu/, accessed on November 25, 2017.

${ }^{28}$ S. Perović, Pravno-filozofske rasprave, Službeni list SRJ, Beograd 1995, 156.
} 
properly to be treated alike in like circumstances" ${ }^{29}$, and "this equality of treatment in turn serves to limit bias and arbitrariness and allows parties to rely with some certainty on how the system has dealt with cases similar to

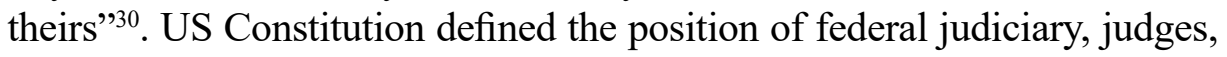
Supreme Court and the Constitution itself, whereby the equity principle is thus defined: "The judicial Power shall extend to all Cases, in Law and Equity, arising under this Constitution, the Laws of the United States, and Treaties made, or which shall be made, under their Authority;--to all Cases affecting Ambassadors, other public Ministers and Consuls;--to all Cases of admiralty and maritime Jurisdiction;--to Controversies to which the United States shall be a Party..." ${ }^{\prime 11}$ In addition to the habeas corpus clause that states that "The Privilege of the Writ of Habeas Corpus shall not be suspended, unless when in cases of rebellion or invasion the public safety may require

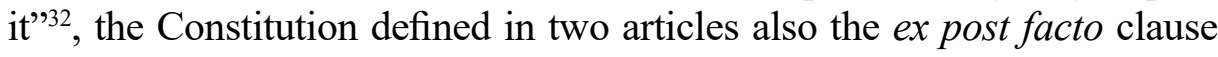
as a strong mechanism of legal certainty, based on the Calder v. Bull of $1798^{33}$ : „No Bill of Attainder or ex post facto Law shall be passed.... ${ }^{34}$ No State shall enter into any Treaty, Alliance, or Confederation; grant Letters of Marque and Reprisal; coin Money; emit Bills of Credit; make any Thing but gold and silver Coin a Tender in Payment of Debts; pass any Bill of Attainder, ex post facto Law, or Law impairing the Obligation of Contracts, or grant any Title of Nobility." 35

On the other hand, the Articles of Confederation do not mention the citizen as a political subject, or the rights of the citizen related to judicial proceedings and ensuring equity. The Articles of Confederation perceive the US as "firm league of friendship with each other" where "Each state retains its sovereignty, freedom, and independence, and every power, jurisdiction, and right, which is not by this Confederation expressly delegated to the United States, in Congress assembled" ${ }^{\text {"36. }}$. Based on the mutual trust of members of the Confederation, the Articles defined that "Full faith and credit shall be given in each of these States to

\footnotetext{
${ }^{29} \mathrm{~W}$. Burnham, Introduction to the Law and Legal System of the United States, Wayne State University Law School, $2003^{3}, 64$.

${ }^{30}$ Ibid.

${ }^{31}$ US Constitution, Article 3, Section 2.

${ }^{32}$ US Constitution, Article I, Section 9.

${ }^{33}$ Calder v. Bull, 3 US 386, 1 L. Ed. 648, 1 L. Ed. 2d 648 (1798).

${ }^{34}$ US Constitution, Article I, Section 9.

${ }^{35}$ US Constitution, Article I, Section 10

${ }^{36}$ Articles of Confederation and Perpetual Union, also known as the first US constitution. Approved on November 15, 1777 by the Second Continental Congress, put into force in 1781. They were created upon the premise of independence of 13 colonies now states, while the US was ineffective, weak and without concrete power to exercise. The Articles were replaced by the US Constitution in 1787.
} 
the records, acts, and judicial proceedings of the courts and magistrates of every other State" ${ }^{37}$, not affecting on any ground the judicial systems or legal frameworks of Union member states. ${ }^{38}$ In this way equity and legal certainty were left completely to the Confederation states to regulate as they wished. Bearing in mind the problems and circumstances that led to creating a firmer alliance and US Constitution, it may be concluded that legal certainty and equity in judicial proceedings were among fundamental issues to be solved by the new constitution, since the confederation experience revealed the negative consequences of insufficiently clear legal categories.

In parallel with common law practice, the development of written legislation influenced the strengthening of fusion of law and equity, but now in the opposite direction. Unlike Continental law, based on written law as a general legislation framework allowing a broader range of interpretations in particular judicial proceedings, American laws go into more detail. They do not allow hues and shades in interpretation but require literal enforcement of their letter in the final judicial decision. That is a specific "common law approach toward statutes that differs from the approach taken in most civil law countries. Common law judges see statutes as containing specific rules of law that will be applied fairly according to their terms, but not beyond. Subject matter outside the terms of the statute remains governed by the common law. This means, as a general rule, US courts will not interpret statutes in two ways that are routine in the civil law countries". ${ }^{39}$

This seemingly contradictory position of common law v. written law in the context of interpretation is an efficient mechanism of legal certainty for citizens facing the institutions of the system. Detailed definitions in written acts and their literal enforcement protected many civil rights from the tyranny of the legislator. On the other hand, however, the breadth of interpretation presents in common law resulted in many legal situations interpreted in line with the customs of the time, overall social changes, and based on judicial experience. The main "question actually is how to regulate specific social relationships through the legal norm without allowing the exclusive requirements of formal legal application to harm

\footnotetext{
${ }^{37}$ Articles of Confederation, Section IV.

${ }^{38}$ At the same time, in the $9^{\text {th }}$ article of the Articles of Confederation is written that "The United States in Congress assembled shall also be the last resort on appeal in all disputes and differences now subsisting or that hereafter may arise between two or more States concerning boundary, jurisdiction or any other causes whatever".

${ }^{39}$ W. Burnham, 50.
} 
the sense of equity, or to prevent the exclusive requirements of equity from threatening the principle of legal certainty". ${ }^{40}$ This is the topic that attracted the attention of federal courts in many judicial proceedings that indirectly or directly dealt with economic and social relations during $19^{\text {th }}$ century in particular.

\section{Concluding remarks}

The English legacy in US legal system has actually two main parallel tracks: English common law legacy on one hand and the Lockean philosophical legacy. The heritage of English common law system made it possible to protect, through the precedent doctrine and the principle of equity, the freedoms and rights of US citizens in the period of forming the USA. Over time, English legal heritage, combined with specific characteristic of colonial life in North America, created a separate legal space where the common law system suffered radical changes that remained typically American. Partiality for legal regulation, legal logic and juristic system of thought gave rise to many particularities of the US legal system. Detailed definitions in written acts and their direct application protected many civil rights from the tyranny of the legislator. On the other hand, however, the extensiveness of interpretation in common law led to many legal situations being interpreted in line with the customs of the time, overall social changes and based on the case law. Legacy of natural rights narrative, however, altogether with the issue of the just and responsible government established by consent of the governed and constrained by legislature, is the cornerstone of the US ideological legacy, embedded in the Declaration of Independence and in one of the most progressive section of the US Constitution, Bill of Rights.

\section{References}

Burnham, W., Introduction to the Law and Legal System of the United States, Wayne State University Law School, $2003^{3}$.

Clark, D. S. and Ansay, Turgul (eds.), Introduction to the Law of the United States, Kluwer Law International, The Hague 2002.

Ćeranić, J., „Izvori američkog prava“, Uvod u pravo SAD (ed. Jovan Ćirić), Institut za uporedno pravo, Beograd 2008.

Danković Stepanović, S., Pravo i politika konkurencije, Beograd, Fakultet ${ }^{40}$ S. Perović (1995), 156. 
političkih nauka, 2014.

Farnsworth, E.A., Uvod u pravni sistem Sjedinjenih Američkih Država, Beograd, Savremena administracija 1973.

Hamilton, A., Medison, Džejms, Džej, Džon, Federalistički spisi, Beograd, Radnička štampa, 1981.

Perović, S., Besede sa Kopaonika (1990-1996), Beograd, sopstveno izdanje, 1997.

Perović, S., Pravno-filozofske rasprave, Službeni list SRJ, Beograd, 1995.

Vranjanac, D., "Uvod u pravni sistem Sjedinjenih Američkih Država“, Uvod u pravo $S A D$ (ed. Jovan Ćirić), Institut za uporedno pravo, Beograd 2008.

West, W. M. (ed.), A Source Book of American History to 1787, Allyn and Bacon, Boston-New York-Chicago 1913.

\section{Legal sources}

United States Constitution, https://www.archives.gov/founding-docs/constitution-transcript.

Articles of Confederation, Avalon Project, Document in Law, History and Diplomacy, Yale Law School, Lillian Goldman Law Library, http://avalon.law.yale.edu/18th_century/artconf.asp.

Magna Carta Libertatum (1215), https://www.bl.uk/collection-items/ magna-carta-1215.

\section{Website references}

Brogan, D. W., The Highest Office, http://www.americanheritage.com/ content/highest-office, last accessed November $2^{\text {nd }}, 2017$.

Foner, E., Radical Individualism in America: Revolution to Civil War, https:// www.libertarianism.org/publications/essays/radical-individualism-america-revolution-civil-war, last accessed November $27^{\text {th }}, 2017$.

Knežević, R., O pravdi, pravičnosti, pravu, https:// blog.aks.org.rs/o-pravdi-pravicnosti-pravu/, last accessed November 25, 2017. 


\title{
Dr Gordana Bekčić Pješčić
}

Nezavisni konsultant, GBP Consulting

\section{AMERIČKI PRAVNI SISTEM U KONTEKSTU ENGLESKOG PRAVNOG NASLEĐA I TEORIJE PRIRODNIH PRAVA DŽONA LOKA}

\author{
Rezime
}

Rad razmatra neke osobenosti američkog pravnog sistema koje su utemeljene na engleskom pravnom nasleđu koje su prvi engleski kolonisti doneli u Severnu Ameriku. Autorka polazi od pretpostavke da su stalne izmene osnovnih principa engleskog sistema običnog prava i pravne i sudske prakse dovele do određenog američkog pravnog sistema koji ima dvostruku prirodu, zasnovanu na principima common law sistema sa jedne strane i slova pisanog zakona sa druge. Rad analizira i fundamentalan uticaj filozofskog sistema Džona Loka o prirodnim pravima, statusa svojine i vlade idejna na uspostavljanje američke političke i pravne misli, oličene u Deklaraciji i Povelji o pravima.

Ključne reči: pravni sistem $\mathrm{SAD}$, pravno nasleđe, Ustav $\mathrm{SAD}$, common law, prirodna prava, sudska revizija, precedent. 